\title{
GOODMANOVA TEORIE ZOBRAZENÍ A FENOMENOLOGIE
}

\author{
Ivan Blecha
}

Nelson Goodman je znám nejen jako vlivný analytický filosof, ale i jako myslitel, který inspiroval současnou teorii umění, a to svým pojetím zobrazení a nápodoby. Reprezentativní zpracování této koncepce nalezneme v jeho knize Jazyky umění. Nástin teorie symboli̊.

Filosoficky nejzávažnější je první kapitola této knihy, která pod názvem „Skutečnost znovu ztvárněná“2 uděluje Goodmanovým úvahám hlavní směr. Je zde podána „ontologie“ obrazu, z níž potom vycházejí Goodmanovy teze o povaze umělecké nápodoby a symboliky. Právě tato úvodní pasáž je však také nanejvýš problematická a lze vůči ní vznést účinnou kritiku z pozic fenomenologie. Svou interpretaci, na jejímž základě tuto kritiku představím, souběžně opřu o komentáře k dalším Goodmanovým textům, které se dané problematiky rovněž týkají. ${ }^{3}$

Máme-li se podle Goodmana zabývat otázkami umění, je třeba začít u zásadního procesu, který umění v různých formách doprovází od počátku, totiž u procesu zobrazení. Goodman se pokouší obecně přijímané pojetí zobrazení vyjádřit striktně následující formulí: „A zobrazuje B tehdy a pouze tehdy, když se A rozpoznatelně podobá B.“ Nebo jinak:

1 N. Goodman, Jazyky umění. Nástin teorie symbolů, přel T. Kulka et al., Praha 2007. V českém překladu se pracuje s pojmy ,zobrazení“ a „nápodoba“, resp. ,,podobnost“. V originále jsou anglickými ekvivalenty těchto pojmů „representation“, resp. „depiction“, a „,imitation“, resp. „resemblance“ (srv. N. Goodman, Languages of Art. An Approach to a Theory of Symbols, Indianopolis - New York - Kansas City 1968).

2 N. Goodman, Jazyky umění, str. 21-48.

3 Rád bych na tomto místě upřímně poděkoval recenzentům tohoto článku. Věnovali mému textu velkou pozornost a navrhli řadu důležitých a zajímavých úprav. Některé z těch menších jsem do článku zapracoval. Další mají podle mého soudu spíše povahu poznámek k diskusi, na kterou v tomto textu (už tak rozsahem napjatém) není dost místa. Beru je jako podněty k případným úvahám nad problémy, k nimž bych se někdy mohl vrátit. 
„A zobrazuje B do té míry, do jaké se A podobá B.“4 Goodman soudí, že pokud zformulujeme tezi o povaze zobrazení takto hutně, musí si každý soudný člověk ihned uvědomit, jak je naivní a mylná. Goodman zdůrazňuje, že více chyb do tak krátké teze snad ani nashromáždit nelze. Důvodem je, že se má zcela samozřejmě za to, že zobrazení musí určitým způsobem souviset s podobností. Podle Goodmana je však možné uvést mnoho příkladů, které jasně ukazují, že ,žádná míra podobnosti není postačující podmínkou pro zobrazení“. 5 Pokud má obraz nějaký objekt zobrazovat, musí jej „označovat, zastupovat, odkazovat k němu“ a pro takový vztah reference žádná míra podobnosti nemůže stačit. Ona vlastně ani není nutná. ${ }^{6}$ Mohou existovat obrazy, které nemají referenty, a nemají se tedy čemu podobat (například obraz kentaura). Anebo existují abstraktní obrazy, které vůbec nic nezobrazují. Můžeme-li však takovým obrazům docela dobře porozumět, nemůže to být podobnost, co takové porozumění zakládá. ${ }^{7}$ Někdo by snad mohl namítnout, doplňuje Goodman, že podobnost je přinejmenším onen specifický rys zobrazení, který je odlišuje od jiných druhů denotace. Ale ani s tímto skromnějším vyjádřením není Goodman spokojen.

Nebudu se pouštět do podrobnější polemiky s analýzami, které Goodman obecně problému podobnosti věnuje. $\mathrm{V}$ mnoha ohledech jsou to analýzy přínosné a pro teoretiky umění i jazyka a sémiotiky důležité. Jiná otázka je, že východiskem pro tyto Goodmanovy rozbory (a tedy pro celou koncepci nápodoby jako pochybné podmínky zobrazování) je tvrzení, že u žádné formy reprezentace nemůžeme uspokojivě mluvit o nápodobě zobrazované věci především proto, že neexistuje „pravý“ způsob, jakým se věci jeví. ${ }^{8}$ Nenajdeme žádný ,privilegovaný““ aspekt, který by se měl napodobit, a už vůbec nelze předpokládat, že objekt uvidíme z ideální pozice tak, aby jeho př́ípadná nápodoba pokryla vše, co k němu patř́í. To by předpokládalo pozici „nevinného oka“ a ta je nemožná:

„Teorie zobrazení jako nápodoby tedy na samém počátku ztroskotává na neschopnosti upřesnit, co má být vlastně napodobeno. Není to ani

\footnotetext{
$4 \quad$ N. Goodman, Jazyky umění, str. 21.

5 Tamt., str. 22.

6 Tamt.

7 N. Goodman - C. Z. Elginová, Nové pojetí filozofie a dalších umění a věd, přel. T. Kulka et al., Praha 2017, str. 140.
}

8 N. Goodman, Jazyky umění, str. 23. 
objekt takový, jaký je, ani všechny způsoby, jakými je, ani to, jak se jeví bezduchému oku. “9

Právě toto tvrzení považuji za velmi sporné. Do jaké míry jeho případné zpochybnění ohrožuje celou Goodmanovu koncepci, neumím zodpovědně rozhodnout. Bez ohledu na to však platí, že diskuse nad tímto dílčím problémem může být zajímavá a může přinést náměty do rozpravy o „realismu“, která je v mnohých směrech analytické filosofie velmi živá. ${ }^{10}$

Tomu, aby nějaký obraz věrně napodoboval objekt tak, jak ve skutečnosti je, překážejí podle Goodmana dvě základní omezení. Předně: co je to „objekt, jak skutečně je“? Je to souhrn všech jeho vlastností a pozic, všechny možné způsoby, jakými existuje? Nikoli, nebot' jaký by byl onen ,pravý“ způsob, jakým nějaký objekt existuje? Je člověk přede mnou shluk buněk, šumař, př́tel, pijan? Je všechno naráz, nebo je něčím z toho přednostně? Uvedený nárok by však bylo možné zmírnit, přičemž bychom se mohli spokojit s tím, že věrně napodobíme jen jeden takový aspekt, jeden ze způsobů, jak se objekt jeví, a to ten, jak se jeví normálnímu oku prostému náklonnosti a osobních zájmů, umístěnému v ideální pozici, bez rušivých vlivů a bez vlastních interpretací. ${ }^{11}$ Takové nevinné oko však neexistuje. „Nejen jak, ale i co oko vidí, se řídí potřebami a předsudky. Vybírá si, odmítá, pořádá, rozlišuje, spojuje, třídí, analyzuje, tvoří.“"12 Tedy spíše než že by naše oko zrcadlilo, uchopuje a vytváŕí - nic nemůže vidět nahé, ani naze. ${ }^{13}$

Nepřiznanými podmínkami „objektivního zobrazení“ jakožto nápodoby jsou tedy nesplnitelné požadavky na všestrannou a snadno dostupnou danost objektu a na nevinné oko. ${ }^{14}$ Protože však vnímání a interpretaci nelze od sebe oddělit, nikdy nerozeznáme, co z viděného je daností a co naším vkladem..$^{15}$ Neexistuje jedno jediné správné vnímání světa, které by bylo možné napodobovat či kopírovat. Vzhled světa není dán, je konstruován. Nevinné oko, potažmo privilegovaný realismus, neexistuje. Proto neexistuje ani žádná přirozená relace stojící v pozadí reprezentace

9 Tamt., str. 25.

10 Srv. např. T. Marvan, Realismus a relativismus, Praha 2014.

11 N. Goodman, Jazyky umění, str. 23.

12 Tamt., str. 24.

13 Tamt.

14 Tamt.

15 Tamt. 
(jakou by měla být právě kritizovaná relace podobnosti). ${ }^{16}$ Měli bychom správně ř́kat, že to, co napodobujeme, je vždy nějaká naše interpretace. To zní ovšem s ohledem na běžné pojetí nápodoby dost absurdně, proto máme podle Goodmana raději říkat, že výklady nebo interpretace nenapodobujeme, ale že k nim dospíváme: ${ }^{17}$

„Realismus zobrazení tedy nemá záviset na podobnosti per se. Je ale možné realistickou reprezentaci považovat za reprezentaci pomocí zavedené konvence, kde ona konvence je právě relativní vůči danému kulturnímu milieu. Denotace je za tohoto stavu věcí podstatně arbitrární, v Peircově terminologii ,symbolická‘, bez jakékoliv vazby na intuitivní realismus.“18

Podle Goodmana tedy platí, že každé napodobení je jen různou formou převyprávění reality:

„... jak to nejneutrálnější, tak to nejpředpojatější oko jsou pouze jinak rafinované. Nejasketičtější a nejrozmařilejší vidění, jako třeba střízlivý portrét a jedovatá karikatura, se od sebe liší nikoliv mírou, nýbrž jen způsobem interpretace. “19

Karikatura není více ani méně podobná realitě než fotografie. Platí proto, že v cestovním pasu by beze všeho mohla být karikatura. Není tam a nemůže tam být nikoli proto, že by fotografie byla věrnějším zobrazením skutečnosti, ale proto, že žijeme ve společnosti, která si fotografii určila jako normu zobrazení. Míra „věrnosti“ se zde stanovuje ve vztahu k této konvenci, nikoli ve vztahu k realitě. V jiné společnosti by to docela dobře mohlo být jinak. Naše schopnost vidět vůbec něco na fotografii, a dokonce ji považovat za zvlášt' vhodný a přesný způsob reprezentace je tedy kulturním výdobytkem, nikoli faktickou dispozicí fotografie. Goodman připomíná, že třeba afričtí nebo australští domorodci hledí na fotografii zcela nechápavě a neumějí rozpoznat, že vůbec něco zobrazuje. Goodman nakonec nachází

16 R. Niederle, Reprezentace: podobnost, souvislost, symbol, in: L. Dostálová T. Marvan (vyd.), Studie k filosofii Nelsona Goodmana, Praha 2012, str. 69.

17 N. Goodman, Jazyky umění, str. 25.

18 R. Niederle, Reprezentace: podobnost, souvislost, symbol, str. 79.

19 N. Goodman, Jazyky umění, str. 25. 
kritérium zobrazení v tom, co Ján Hrkút ve zkratce charakterizuje jako ,indoktrinaci““: ${ }^{20}$

„Realismus nespočívá v nějakém stálém či absolutním vztahu mezi zobrazením a zobrazovaným, ale ve vztahu mezi systémem zobrazení použitým v obraze a systémem standardním." ${ }^{21}$

Realistické je tedy jednoduše to, co je v dané společnosti díky kulturní tradici, formám života a přsesvědčení za realistické považováno. Dnešníma očima se nám egyptské zobrazení žní zdá strnulé, ploché, tedy schematické, a vůbec ne realistické. Egypt'anům se naopak jako realistické zdálo a zřejmě by nerozuměli našemu způsobu malování. Stejně by tomu bylo ve středověku s ikonami či s obrazy bez perspektivy. Musíme si uvědomit, že v naší oblasti a v naší době často považujeme obrazy za realistické či doslovné jen proto, že mají tradiční evropský styl zobrazení, a nikoli proto, že by tyto obrazy byly zdařilou „nápodobou“ objektu o sobě. ${ }^{22}$ Van Goghovo Obilné pole se spíše než skutečnému obilnému poli podobá jiným obrazům, což v konečných důsledcích musí vést k závěru, že cokoli se může podobat v nějakém ohledu čemukoli jinému:

„...to, zda van Goghovo Obilné pole reprezentuje (resp. denotuje) duševní stav autorův nebo napodobuje konkrétní obilné pole v Auvers-sur-Oise závisí na tom, zda obraz Obilné pole náleží do systému symbolů malîřského expresionismu sklonku 19. století či nikoli. Porozumět obrazu znamená znát jazyk onoho expresionismu, jeho ,slovník' (množinu obrazů) i ,gramatiku' (množinu charakteristických vlastností obrazů-prvků systému expresionismu).“23

Realismus je věcí zvyku:

„To, že se obraz podobá přírodě, často pouze znamená, že vypadá tak, jak bývá prríroda zpravidla malována. A opět to, co mne svádí $\mathrm{k}$ domněnce, že vidím před sebou objekt jistého druhu, závisí na tom,

20 J. Hrkút, Nelson Goodman a otázka realismu, in: L. Dostálová - T. Marvan (vyd.), Studie k filosofii Nelsona Goodmana, str. 59.

21 N. Goodman, Jazyky umění, str. 44.

22 Tamt.

23 R. Niederle, Reprezentace: podobnost, souvislost, symbol, str. 79. 
čeho jsem si u těchto objektů všiml, což je zas ovlivněno tím, jak je zpravidla vidím zobrazeny.“24

Vše tedy vyplývá „,z konceptuálních a percepčních zvyklostî“ ${ }^{25}$ Realističnost zobrazení není vně nás, ale uvnitř našich recepčních a interpretačních center a jimi osvojených standardů - skrze ně vnímáme obraz, ale nakonec i realitu. Standardní systém je pak ten, který má recipient nejvíce zažitý. ${ }^{26}$

„Pro rozpoznání způsobů, jakými obraz zpodobňuje svůj předmět, stejně jako dalších vlastností obrazu, je třeba vědět, jak se na obraz dívat. Zapotřebí mohou být také znalosti jiného druhu - zobrazovací konvence, referenční spojení, historická, vědecká či metodologická tradice, které ustavují kontext daného díla. Takových znalostí nenabýváme pouhým pohledem.“27

Dítě, které se učí odlišit koně od zebry pomocí jejich obrázků, se současně učí odlišovat i obrazy koní od obrazů zeber. Medik, který se učí poznávat chorobou napadené orgány studiem lékařských textů, se zároveň učí interpretovat anatomické ilustrace. ${ }^{28}$ Tím se získává obrazová kompetence:

„Jakmile ovládneme obrazový systém, tak prostě vidíme, co obrazy, které k němu náležejí, zobrazují. Tento proces je natolik zautomatizován, že si často neuvědomujeme, že se vůbec o nějakou interpretaci jedná.“29

Ještě jeden argument pro podporu svého stanoviska Goodman uvádí: podobnost je vždycky vztah symetrický, a proto není možné uznat podobnost mezi obrazem královny a královnou samotnou. Symetrii můžeme najít maximálně mezi dvěma obrazy téhož ražení, např́́klad mezi

\footnotetext{
24 N. Goodman, Jazyky umění, str. 45.

25 Tamt.

26 J. Hrkút, Nelson Goodman a otázka realismu, str. 60.

27 N. Goodman - C. Z. Elginová, Nové pojetí filozofie a dalších umění a věd, str. 142 .

28 Tamt.

29 Tamt., str. 143.
} 
těmi, jež jsou shodně dvojrozměrné, zarámované, namalované olejovými barvami atp.

Podle Goodmana je proto vhodnější užívat místo pojmu podobnosti pojem reprezentace: obraz zobrazovanou věc reprezentuje - a to se děje různými symbolickými procedurami (ve smyslu Peircova rozlišování ikon, indexů a symbolů).

Jedním z prostředků, jak se v minulosti malîri pokoušeli realisticky zobrazit svět, který vnímali, a tedy i prostor, v němž se jim nabízel, bylo podle Goodmana užívání perspektivy: „Zákony perspektivy by měly poskytnout absolutní měřítko věrnosti, které je nadřazeno rozdílům ve způsobu vidění a zobrazení.“" ${ }^{30}$ Goodman pak problému perspektivy věnuje celou jednu podkapitolu úvodní části. Jeho analýza „perspektivního vidění“ je příznačná pro celé jeho pojetí zobrazení, proto se na ni podíváme podrobněji.

Že se perspektiva z principu nemůže stát vhodným prostředkem $\mathrm{k}$ tomu, aby zajistila zobrazení podobu se zobrazovaným předmětem, ukazuje Goodman na jednom myšlenkovém experimentu:

„Představme si, že máme statický jednobarevný objekt, který odráží pouze světlo střední intenzity. Obhájci věrnosti perspektivy tvrdí, že obraz nakreslený ve správné perspektivě bude za stanovených podmínek vysílat k oku přesně takový svazek světelných paprsků jako objekt sám. Věrnost zobrazení se zakládá právě na této shodě, jež je zcela objektivní, nebot' je změřitelná přístroji. Jelikož oko přijímá od objektu i od obrazu právě a jen světelné paprsky, totožnost jejich uspořádání je nutně totožností vzhledu. “31

Zdá se pak, že když dodržíme pokud možno shodné podmínky pozorování, nelze tvrzením o podobě předmětu a obrazu nijak otřást. Goodman však upozorňuje, že je to omyl. Oko se nikdy nemůže učinit sterilně nehybným, aby v obou případech vidělo stejně. Oko vidí jen tehdy, když se hýbe, když klouže po struktuře, kterou vnímá, a v tom př́ípadě je struktura obrazu (který je prostě plochý a který je v určité vzdálenosti) a objektu (který plochý není a který se jeví v určité vzdálenosti) odlišná, takže nutně musí být odlišný i dopad paprsků na sítnici, jejich intenzita a zabarvení. A to podle Goodmana nemluvíme o vlivu předchozí zkušenosti, která také bude v každém z obou případů jiná, a bude mít tedy rozdílný

\footnotetext{
30 N. Goodman, Jazyky umění, str. 26.

31 Tamt., str. 26-27.
} 
vliv na vnímání. Kromě toho je rovněž jasné, že umělec dobře ví, že jeho obrazy budou prohlíženy $\mathrm{v}$ rámech na zdi, tedy za specifických světelných podmínek a z určitého odstupu. Vše nasvědčuje tomu, že každé zobrazení je prostě určitý druh překladu, který vyrovnává rozdíly v okolnostech vnímání. Perspektivu se vlastně musíme učit číst - svědčí o tom zajímavé konflikty při pohledu na malîrské práce různých kultur, třeba těch, které perspektivu neznají nebo které bez rozpaků užívají více perspektiv najednou (jak je tomu například u čínských krajinomaleb). ${ }^{32}$

Je tedy zřejmé, že perspektiva, do níž zastánci realistického zobrazení vkládali tolik nadějí, nemůže být věrným zachycením toho, jak vidíme svět. Tento Goodmanův závěr se zdají podporovat i „fyziologické“ aspekty perspektivního vidění. Kdybychom totiž nechali perspektivu volně působit a to, co vidíme, pak opravdu zachytili věrně, divili bychom se, jak křivě a pokrouceně vidíme. ${ }^{33}$ Jak na obraze, tak třeba na fotografii nebo na soše v plenéru musíme proto zobrazené různě upravovat, sloupy nebo hrany domů se například musí nepřirozeně „,narovnávat“, aby na obraze nepadaly, nebot' $v$ reálné perspektivě je vidíme šikmo. $\mathrm{Na}$ moderních fotoaparátech máme dokonce zařízení, která umožňují přirozená pokřivení perspektivní geometrie automaticky retušovat. Koleje necháváme sbíhat, protože to odpovídá naší běžné zkušenosti, sloupy ale narovnáváme, protože u nich převládne výklad, že přece samy o sobě stojí rovně. Zkrátka: „Perspektiva není ani absolutním, ani nezávislým měřítkem věrnosti. “34 Perspektiva je proto u Goodmana nenápadně zasunuta mezi „symbolické formy“ Cassirerova ražení, a tím do konvenčních, kulturně podmíněných forem názoru. Hraje tu roli jakéhosi „výtvarného jazyka“.

V následujících částech knihy Jazyky umění se pak Goodman v souvislosti s výchozí kritickou analýzou pojmu podobnosti věnuje dalším možným formám zobrazení či reprezentací (např́íklad exemplifikaci, tj. zastupování vzorem či vzorkem, jež souvisí s problémem metafory), ${ }^{35}$ a následně problému padělků, nebot' v souvislosti s otázkou po podobnosti se samozřejmě vynoří další otázka, zda je dokonalý padělek stejně ,podobný“ zobrazenému objektu jako originální obraz. Přitom se lze ptát, v čem by spočívala estetická hodnota padělku a zda ji vůbec

\footnotetext{
32 Tamt., str. 29.

33 Tamt., str. 31-32.

34 Tamt., str. 32.

35 K tomu také N. Goodman - C. Z. Elginová, Nové pojetí filozofie a dalších umění a věd, str. 150-151.
} 
ve srovnání s originálem může mít. Kromě toho se Goodman zabývá různými formami „symbolického zobrazeni““ v umění, např́íklad notací hudebního díla či náčrtem plánu stavby atp. Všechny tyto analýzy jsou velmi poutavé a v dílčích sestupech do hloubky problému jistě i nesmírně cenné pro teoretiky umění. Avšak to, co nás zde zajímá, už Goodman dále nerozvíjí, spíše na tom jen dále buduje.

Poučeni výše uvedenými analýzami, budeme méně překvapeni, když nyní u Goodmana najdeme následující radikální tvrzení, která ho řadí po bok některých relativistů a která umožňují, aby z něho čerpali někteří postmoderní myslitelé:

„Je-li zobrazování tříděním objektů, a ne jejich nápodobou, charakteristikou, a nikoli kopií, pak nejde o pasivní záznam. Objekt před námi nesedí jako poslušný, vzorně upravený model vybízející k obdivu a k zvěcnění. Je jedním z nesčetných objektů, může být přiřazen k jakémukoli jejich výběru a každému takovému seskupení odpovídá nějaká jeho vlastnost. Brát všechna třídění jako rovnocenná je totéž jako netřídit vůbec. Klasifikovat znamená upřednostňovat. Užití nějakého označení (obrazového, verbálního či jiného) třídění uskutečňuje právě tak, jako je jeho záznamem. ,Přirozené‘ druhy jsou prostě ty, které jsme si zvykli pro označení a označením vybírat. Navíc samotný objekt není k dispozici předem, nýbrž je výsledkem způsobu, jakým chápeme svět. Tvorba obrazu se spolupodílí na tvorbě toho, co má být zobrazeno. Objekt a jeho vlastnosti závisí na uspořádání a všechny druhy označení jsou nástroji tohoto uspořádání.“" ${ }^{36}$

„Zobrazení i popisy tedy organizují a samy jsou často organizovány... Všemi těmito způsoby však mohou zobrazení a popis dle toho, jak sdružují a jak jsou samy sdružovány, vytvářet či označovat spojení, analyzovat objekty a uspořádávat svět.“37

„Vyčlenění nových prvků či kategorií, anebo těch dobře známých pomocí nových druhů označení či novou kombinací označení vžitých, může vést k novým vhledům. ... Svět je produktem umění a jazyka." ${ }^{38}$

\footnotetext{
36 N. Goodman, Jazyky umění, str. 40.

37 Tamt., str. 41.

38 Tamt.
} 
Shrňme na závěr této části hlavní Goodmanovy teze. Nelze-li přesvědčivě doložit, že zobrazení (a každá denotace) závisí na podobnosti, tj. na vykazatelné referenci k realitě, již nějak odráží, pak je realita přístupná vždy jen symbolicky, a tedy konvenčně. Vyjádřeno ještě ostřeji: realita je jistě nějak strukturována, její strukturu však nemůžeme nijak kopírovat ve strukturách zobrazení, protože tu není žádná korespondence, žádný závazný předpis nebo tlak ze strany reality. Realita je ve vnímání vždy nějak zastupována, ale skrze dispozice, které máme my a které neodpovídají dispozicím reality: jsme vždy nějak omezeni, vždy stojíme na určitém místě, rozevíráme nějakou dílčí perspektivu. Abychom mohli předpokládat, že struktura vnímání pokrývá beze zbytku, věrně a objektivně strukturu reality, museli bychom být v pozici nevinného nebo božího oka, tedy v pozici, v níž bychom nezkresleně a nezaujatě viděli „všechno“. Takovou pozici však nelze zaujmout, proto je rovněž nemožné ideální zobrazení a ideální podobnost. Není-li ale zobrazení ideální, tj. není-li dokonalou nápodobou, ztrácí vlastně svůj smysl a je zbytečné se jím zabývat jako náležitostí „realistického“ zachycení objektivní reality. Proto Goodman otevřeně vyhlašuje:

„Mýtus o nevinném oku a mýtus o absolutně daném jsou čertovi tovaryši. Oba mýty vycházejí z představy, kterou zároveň posilují, že poznání je zpracování surového materiálu dodaného smysly, ke kterému lze nalézt cestu zpět v očistných rituálech či metodickým odstraněním nánosů interpretace. Jenže vnímání a interpretaci nelze od sebe oddělit, jsou to dvě vzájemně zcela provázané operace. Ozývá se nám tu kantovské diktum: nevinné oko je slepé a neposkvrněná mysl prázdná. Stejně nikdy nerozeznáme, co z viděného je daností a co naším vkladem. Nedokážeme vydobýt obsah prostým sloupnutím vrstev výkladů.“39

Z řečeného plyne následující závěr:

„Výsledkem našeho dosavadního počínání je, že jsme zobrazení a popis podřadili denotaci. Zobrazení jsme tak osvobodili od zvrácené představy idiosynkratického fyzikálního procesu podobného zrcadlení a ukázali jsme, že jde o relativní a proměnlivý znakový vztah. Navíc jsme tím zobrazení odlišili od nedenotativních způsobů reference. “40

\footnotetext{
39 Tamt., str. 24.

40 Tamt., str. 47-48.
} 
Pokusím se nyní o kritiku Goodmanovy koncepce. V jejím základu nalezneme určitou teorii vnímání a smyslové zkušenosti, která se opírá o několik bezproblémově přijímaných předpokladů. Právě na tyto předpoklady se chci zaměřit.

\section{Zkreslení a „nevinné oko“}

Vnímání je podle Goodmana vždy určitou interpretací, danou našimi omezenými dispozicemi a řízenou našimi zájmy. Nelze vidět objekt ze všech stran najednou. Každý aspekt, způsob jevení objektu, je dán jako produkt zkreslení, jako výsledek našeho výběru, trrídění a rozlišsování.

Goodman tedy vychází z teze, že „zkreslení“, které je spjato s naším vnímáním světa, překáží správnému, objektivnímu či pravdivému zachycení reality a musí být považováno za jistou formu uchopování světa, a tedy jeho interpretace. „Nebot' aspekt není prostě ,objekt z určité vzdálenosti a úhlu a v určitém osvětlení “, je to objekt, jak ho nahlížíme či uchopujeme, jedna z jeho verzí, jeden z možných výkladů ." ${ }^{41}$ Jak ale Goodman k tomuto silnému tvrzení dospěl? Domnívám se, že jde o tvrzení nezdůvodněné a neudržitelné. Lze snadno dokázat, že tzv. zkreslené vnímání může naopak náš rozhled po realitě obohacovat, a to dokonce více, než by toho bylo schopno tzv. nevinné oko.

Vezměme př́klad: kruhový otvor hrnku se jeví jako elipsa. Elipsa je v tomto prrípadě jevovou formou kruhu, je oním aspektem jeho struktury, který se nabízí vnímajícímu zraku. Goodman by zřejmě tvrdil, že elipsa je zkreslené podání kruhu, ovlivněné tím, na jakém místě se my jako nazírající nacházíme, z jaké perspektivy a s jakými dispozicemi jej vnímáme, což by už bylo možné považovat za primitivní, ale rozhodující příklad „vybírání“, „odmítání“, rozlišování a uchopování - všech těch zájmových a subjektivních aktivit, jež musí provádět ,angažované“, tedy u Goodmana ,předpojaté“ oko.

To je jistě v určitém ohledu pravda, ale jednoduchá úvaha postačí k tomu, abychom si uvědomili, že Goodmanovo hodnocení této výchozí pozice není správné. Elipsa je sice jevovou formou kruhu, ale vypovídá cosi zásadního o jeho povaze a je k ní vázána tak pevně, že můžeme hovořit o závazné struktuře zjevování. Jako elipsa se totiž určitě nemůže jevit čtverec nebo trojúhelník. Potud jsou tedy naše „rozlišování“, „vybírání“, „uchopování“, totiž ony aktivity, které Goodman považuje za

41 Tamt., str. 25. 
zkreslující interpretaci, podstatně určeny ze strany vnímaného objektu, takže odpovídají tomu, co patří k jeho povaze. Takových vazeb, v nichž se jevový aspekt, dávající se našemu zraku, ukazuje jako strukturně podmíněný povahou objektu, který se v tomto aspektu jeví, je samozřejmě nekonečné množství a jejich rozpoznáváním, ohmatáváním a uchopováním se učíme správně vidět a účinně jednat. Zkreslení proto není nutně matoucí: ačkoli strukturně není totožné s tím, čeho je jevovým aspektem (elipsa se překrývá s kruhem, který reprezentuje, jen ve čtyřech bodech), může přece typickým a nezaměnitelným způsobem odpovídat tomu, co zjevuje. To, že elipsa kruh zkreslí, ještě neznamená, že ho omezí, zatemní, odsune. Naopak, přivádí nás $\mathrm{k}$ němu, a podává tak zprávu o stavu světa, v němž se kruhovité tvary běžně jeví jako elipsa. Jistě, k tomu, aby v realitě prosadil svůj tvar, kruh sám o sobě nepotřebuje, aby se jako elipsa jevil: tak se jeví nám. Avšak když už se jeví, pak tím způsobem, který nepochybně musí odpovídat jeho dispozicím.

Naše zkušenost se světem se tedy neváže ani pouze na elipsu (a pouze na evidenci jejího tvaru), ani pouze na kruh (a na evidenci jeho tvaru), ale na registraci a na porozumění vztahu těchto dvou tvarů, na jejich propojení, skloubení, na jejich zvláštní asymetrii, protože v dané situaci lze za elipsou dekódovat kruh, ale za kruhem už nelze dekódovat žádný další tvar. „Zkresleně“ snad vidíme kruh (jako elipsu), nebo dokonce samu elipsu (ve špatném osvětlení, v krajním úhlu atp.), nelze však říci, že vidíme ,zkresleně“ poměr elipsy a kruhu, nebot’ ten je dán zcela zřetelně jako jistá zákonitost zjevování určitých tvarů vůči nám jako nazírajícím subjektům. Pro náš život a pro naši orientaci ve světě tak nehraje zásadní roli zkušenost s elipsou a zkušenost s kruhem (což by předpokládalo, že mohou být oddělené, přičemž mezi ně následně vnášíme nějaký interpretační řád), ale zkušenost s jejich vzájemným poměrem: totiž že zkušenost elipsy odkazuje na zkušenost s kruhem, že jedna bez druhé není možná atp. Abychom se tedy ve světě vyznali, musíme umět vyhodnotit nikoli evidenci různých perspektiv a jejich množství, ale evidenci řádu, poměru těchto perspektiv. Protože jde o tuto zkušenost, nedává dobrý smysl hovořit zde o deformování, výběru či rozlišování. Poměr mezi elipsou a kruhem (a tedy poměr mezi zkušenostmi, které s nimi máme) je př́sně dán, nelze jej obracet, opomíjet, podřizovat arbitrárním interpretacím, nahrazovat svévolně řádem znaků. Snad se lze domluvit na tom, že bychom elipsu (a zkušenost s ní), a stejně tak kruh, nahradili určitým kulturně vytvořeným symbolem, např́klad shlukem fonémů, což ostatně v jazyce činíme. I tato symbolická interpretace, jakkoli arbitrární, by však musela respektovat vzájemný poměr kruhu 
a elipsy v dané situaci a tento poměr by musela respektovat i naše práce se symboly.

Právě zde můžeme říci, že arbitrární, tedy věcí domluvy, může být určování, jakými symboly budeme označovat nějaký předmět. Existenci tohoto předmětu a řád vztahů, v nichž se nachází a který je pro něj typický, však smluvně nijak nevytvoříme, a naopak je musíme ve struktuře systému nahlédnout. Není-li konkrétní symbol podobný tomu, co označuje, neznamená to, že by nemohla užívaná symbolika vyjadřovat cosi objektivního, reálného, nebot' ráa symbolů musí respektovat řád zkušenosti o povaze světa, nechceme-li upadnout do nepřijatelných absurdit.

Uved’me jeden př́klad. Pro symbolické ztvárnění sítě pražského metra mohu zvolit řadu určitých symbolů, a poté zase jinou řadu, takže sít' metra může být zobrazena např́íklad větvením, které nijak neodpovídá skutečnému směřování jednotlivých tras v pražském podzemí. Takové „zhuštěné“ symbolické znázornění vídáme například nad dveřmi vozů pražského metra. Cestujícím to však nijak nevadí v orientaci - vystoupí ve správné stanici, přestoupí na požadovanou linku atp. Ostatně tito cestující, lze říci s Goodmanem, stejně nikdy nemohou vidět objektivní stav pražských linek, protože nebudou nikdy v takové pozici, aby ji mohli evidovat $\mathrm{v}$ jejím celku. Pak zřejmě nezáleží na tom, jak bude taková nedostupná sít' znázorněna, hlavně, že bude možné se podle ní účelně a jednoduše orientovat. Potud řečené odpovídá Goodmanovým názorům. Doplňme však, že sousedství stanic na tomto schématu už arbitrárně měněno být nemůže, nebot' $v$ opačném případě by nastal chaos, který už by orientaci v realitě ztížil na maximum. Stanice Staroměstská bude muset být v jednom směru před stanicí Můstek a v opačném směru za ní. Stejně tak obrazec, který vytvářejí přestupní stanice, nebude muset kopírovat podobu reálného trojúhelníku mezi Můstkem, Muzeem a Florencí, ale i přesto, že bude mít $\mathrm{v}$ každém schématu tvar jiný, pokaždé bude ustaven nearbitrárně, s objektivní nutností, na niž nebudeme mít žádný vliv, a pokaždé bude nějak vyjadřovat faktickou podobu sousedství daných stanic. Tento řád objektů, jež necháváme zastupovat různými označeními, už sami nijak utvářet nemůžeme, ten můžeme jenom respektovat, třebaže pomocí ,arbitrárně“ zvolených symbolů. Stěží tedy lze při této př́ležitosti akceptovat Goodmanovo tvrzení, že naše mysl zavádí „, dané doméně řád, stejně jako jej v ní pomáhá rozpoznat“ ${ }^{42}$ nebo že

42 N. Goodman - C. Z. Elginová, Nové pojetí filozofie a dalších umění a věd, str. 36 . 
naše očekávání a přesvědčení „,vedou naše zkoumání a strukturují pole našeho vnímání“.43

Goodman dále píše, že mohou být jen různé způsoby, jak něco je, ale žádný prokazatelně správný způsob, jak být. Z toho odvozuje, že způsoby, jakými objekt je, nemohu ,napodobit všechny zároveň, a čím lépe by se mi to podařilo, tím méně by byl výsledný obraz realistický“. ${ }^{44} \mathrm{Z}$ řečeného je dobře patrné, jak je autorovo tvrzení zavádějící. Otvor hrnku může v jednom zpo̊sobu ,být jako kruh“, v jiném zpo̊sobu „být jako elipsa“. Ze své pozice nemohu ovšem oba způsoby vidět naráz a nemohu je naráz napodobit - právě to má na mysli Goodman. Přesto tento fakt nijak nepřekáží tomu, abych poměr kruhu a elipsy vyhodnotil zcela správně a abych si uvědomil, že tu mám co dělat s reprezentací struktury, která má svůj pevný řád, s nímž nelze libovolně manipulovat. Otvor hrnku má totiž jako základní způsob, jakým jest, nikoli jenom ,,být kruhem“ ani jenom „být elipsou“, ale zvláštní skloubení obojího. To je jeho pravý způsob, jak je: v odkazu elipsy na kruh, v př́tomnosti kruhu v elipse. Zkreslení kruhu do elipsy není kulturně podmíněno, a při jeho vjemové evidenci nemá tedy smysl mluvit o „předpojatosti“ oka. Proto mi také k explikaci zmíněného skloubení, které tu umím nahlížet, nijak nemůže přispět žádný symbolický systém, ani jazyk. Starost o to, jak tuto zkušenost obléci do jazyka, nebo o to, zda jazyk tuto zkušenost omezuje, ruší či teprve zakládá, je pro naši výchozí situaci irelevantní.

Každé zkreslení je ostatně vždy „zkreslením něčeho“. Zdá se však, jako by Goodman zkreslení odděloval od předmětu, jehož je vlastně jevovým aspektem, a činil z něho pouhou subjektivní manýru. Dobře je to vidět na citaci, kterou jsme uvedli už výše: ,aspekt" není pro Goodmana „objekt z určité vzdálenosti a úhlu a v určitém osvětlení“, ale jedna z ,verzí“ objektu, jeden z našich možných výkladů tohoto objektu. ${ }^{45}$ Takové výklady jsou podníceny předchozí zkušeností, zájmy, předpojatostí, vůlí atd. - objekt, jak je o sobě, takto elegantně z Goodmanova zorného pole zmizí.

Podobně pak jiná sugestivně formulovaná poznámka implikuje zmizení reálného světa: když podle Goodmana mluvíme „o způsobech, jimiž svět je“, mluvíme o „způsobech popisování či zobrazování světa“, o ,světa-popisech“ či ,světa-obrazech“. Z toho pak podle autora nemůže nijak vyplývat existence ,něčeho, co popisujeme či zobrazujeme“. ${ }^{46} \mathrm{Od}$

\footnotetext{
43 Tamt., str. 34.

44 N. Goodman, Jazyky umění, str. 23.

45 Tamt., str. 25.

46 Tamt., str. 23.
} 
takových popisů či verzí přitom nelze, jak Goodman uvádí, očekávat žádné svébytné spojování: každé jejich spojení je jen dalším ze způsobů, jak svět vykládáme či zobrazujeme, a nijak nemůže svědčit o strukturách, které by světu náležely o sobě.$^{47} \mathrm{~S}$ ohledem na takové názory pak vskutku nepřekvapí Goodmanovo tvrzení, že „tvorba obrazu se spolupodílí na tvorbě způsobu toho, co má být zobrazeno“. ${ }^{48}$ Objekt a jeho vlastnosti jsou produktem „uspořádání“ a jedinými nástroji takového uspořádání jsou právě jen , všechny druhy označení““ ${ }^{49}$ Uspořádání světa a propojení jeho struktur tedy nelze považovat za objektivně dané, za něco, co bychom mohli nějak nahlédnout, ale jedině za výsledek našich „zobrazení a popisư“. Svět je ,produktem umění a jazyka“.${ }^{50}$ Uspořádání je věcí nikoli pravdivosti, ale platnosti či správnosti: v každém případě je věcí toho, co daná pospolitost akceptuje jako to, co jí vyhovuje, čemu chce věrit, co odpovídá jejím ,předsudkům“, jaké informace si ze „světa“ jako své „verze světa“ vezme. Různé obrazy mohou poskytovat stejné množství informací, a ,informační obsah“ tedy není kritériem realismu, ale pouze základem pro přijetí nebo odmítnutí nějaké „,verze“ světa. ${ }^{51}$ Zobrazení je otázkou volby a „realismus je věcí zvyku“ ${ }^{52}$

Pokud si ale připomeneme to, co vyplývá z našeho příkladu s kruhem a elipsou, pak je tu přece jen určité „spojení“, které není v naší moci a které nemůžeme žádnou tvorbou vnucovat světu tak, aby nakonec byl jen naší interpretací. Jistá zobrazení mohou mít ambici být realistickými, pokud počítají právě s tímto kloubením jednotlivých konfigurací a jevových polí v řádu, který je tu a priori před jakýmkoliv naším zásahem a který je na tomto zásahu nezávislý. Elipsa je zkrátka jevová forma kruhu, a právě kruhu: je to tedy aspekt, který podává objekt z určité vzdálenosti a z určitého úhlu, nikoli jen naše verze, jeden z možných, a tedy ne zcela závazných výkladů. Tvorba realistického obrazu se proto nějak podílí na zachycení jevových aspektů objektu, netvoří však ve všech ohledech to, co zobrazuje: netvoří ,povinnost“" kruhu jevit se jako elipsa, jen ji eviduje. Specifický jevový vztah kruhu a elipsy a zvláštní řád, který panuje mezi oběma perspektivami, v nichž se jeden nebo druhý tvar zračí, pak tedy není „,vecí zvyku“ a obraz, mající realistické

\footnotetext{
47 Tamt.

48 Tamt., str. 40.

49 Tamt.

50 Tamt., str. 41.

51 Tamt., str. 43.

52 Tamt., str. 45.
} 
ambice, se musí tomuto řádu podřídit a musí předpokládat jistou shodnou zkušenost s tím, co zobrazuje, na straně diváka. Pojítko mezi oběma jevovými konfiguracemi přichází ze strany objektu samého, z povahy tvarů, jimž říkáme „kruh“, a není pravda, že „,spojovat lze jen v rámci určitého systému“, myšleno takového, který si sami rozvrhneme svými interpretacemi. To je tvrzení, kterým chce Goodman svou antirealistickou pozici zásadně posílit. ${ }^{53}$

Goodmanovy kritické úvahy na adresu perspektivy proto nesmíme brát jako zcela platné. Jejich nedostatkem je, že pracují s perspektivami „plošně“ a „dichotomicky“. Samozřejmě se tu předpokládá, že ve světě otevíráme jednotlivá vizuální pole, prostírající se z „nulového bodu“ divákova oka, a že jejich stř́́dáním vyměňujeme jednu perspektivu za druhou. Naším základním zjištěním však je, že perspektivy nejsou téhož řádu a že pokud upřeme svůj pohled na jednu z nich, pak spíše než že by spolu jenom sousedily a vzájemně se dichotomicky vytěsňovaly, se permanentně v určitém a určitelném řádu kloubí, nesou a překrývají. Vidím-li tedy právě elipsu, pak perspektiva, v níž jsem otvor hrnku před tím viděl jako „kruh“, zcela nezmizela: kruh se vsunul do elipsy, je v ní, nezmizel za žádný horizont, elipsa je jeho jevovou formou, hapticky je kruh stále dosažitelný. Elipsa je v této pozici vizuální konfigurace, pod níž lze v akci nadále hmatově evidovat konfiguraci jinou, jež se ovšem za jiných okolností rovněž může nabídnout zraku.

Bez ohledu na to, jak vágní jsou v tomto př́ípadě naše úvahy, zůstává zcela zřejmé, že analýza toho, co nám o světě v celku mohou říci jednotlivé perspektivy, odkud mají svůj původ a zda jsou to čistě ,,symbolické formy“ (což s velkou ochotou akceptuje Goodman společně s Panofskym $^{54}$ ), nemůže být tak jednoduše odbyta a že nelze nechat pod perspektivami pohřbít realitu světa o sobě. Perspektiva sama možná vskutku není ,ani absolutním, ani nezávislým měřítkem věrnosti“ " ${ }^{55}$ zmíněný řád perspektiv a jejich specifický poměr však o struktuře světa, dané nezávisle na našich vizuálních aktivitách, už určitou informaci poskytovat může. Fakt, že umělec musí při užití perspektivy tak jako tak porušovat zákony geometrie, ačkoli si původně myslel, že je exaktně užívá pro realistické zachycení světa, potom nic neznamená. Jsou-li mnohem důležitější vazby mezi perspektivami než jejich vnitřní parametry, pak případné umělé

53 Tamt., str. 23.

54 Srv. E. Panofsky, Die Perspektive als ,Symbolische Form“, in: F. Saxl (vyd.), Vorträge der Bibliothek Warburg 1924-1925, Leipzig - Berlin 1927, str. 258 n.

55 N. Goodman, Jazyky umění, str. 37. 
pokřivení těchto parametrů kvůli falešným optickým iluzím - což jsou podle Goodmana právě doklady toho, že jde nikoli o realistické zobrazení, ale o výklady a verze světa - ještě nijak nevylučuje realismus.

Právě zde působí jako korekce fenomenologie, či přesněji, základy, z nichž fenomenologie vychází. Husserl se vždy držel základního východiska: popisy, vyjádření, označení - tedy ony sémantické, a nakonec i sémiotické aktivity, s nimiž pracuje Goodman a celá škola analytické filosofie - musejí být chápány jako pevně napojené na prvotní „,zkušenost se světem“. V mnoha ohledech mají například jazykové výrazy své vlastnosti, své nároky a své způsoby prezentace, to však nesmí zastřít fakt, že artikulují a vyjadřují hlubší „,smysl“: totiž zkušenost se světem, která je již nějak uspořádána, určité uspořádané uchopení forem jeho jevení. ${ }^{56}$ Jazyk toto uspořádání zpřesňuje, objektivizuje, uchovává pro další užití, ale principiálně je nevytváří. Svůj „smysl“ mají tedy vedle jazykových výrazů i naše zkušenostní akty, nebot' právě ony drží předmět $\mathrm{v}$,jak jeho jeveni““ - v oné určité vzdálenosti, v určitém úhlu a osvětlení, od nichž Goodman tak rychle odbíhá. Jazykový výraz je jen znakovou artikulací principiálně už nějak artikulované zkušenosti se světem a tato zkušenost od něho nemůže být oddělena. Jazyk nemá moc rozhodovat o uspořádání struktur reality, o podobě jevových aspektů, nemůže být tvůrcem světa a zřizovatelem spojení, která pak závisejí jen na naší vůli a na našich zájmech. „Proces konstituce vyžaduje neméně nutně i předchůdnou pasivní danost smyslových obsahů, a ta je něčím, co transcendentální subjektivita nemůže nikdy vytvářet ze sebe samé." ${ }^{57}$ Vrstva výrazu není zcela produktivní: je pouhou aktualizací implicitně artikulovaného smyslu. ${ }^{58} \mathrm{Tj}$. smyslový materiál už je pre-artikulován do určitého smyslu, jazyková, výrazová artikulace jej pouze aktualizuje, zpřešnuje, objektivizuje.

Ve všech Husserlových analýzách se proto pracuje s dvojdomou strukturou prožitkového a následně i jazykového aktu: mîrí „,na předmět, který jest", i když k němu vždy mîrí skrze určité prožití, uchopení či vyjádření způsobu, ,jakým onen předmět jest“, tj. jak se jeví nebo jak by se měl vyjádřit. ${ }^{59}$ Goodman naopak nechává to, , ,jak oko vidí“, i to, ,co

56 Srv. např. E. Husserl, Ideje k čisté fenomenologii a fenomenologické filosofii, II, přel. E. Kohák - M. Novák - A. Rettová - P. Urban - H. Janoušek, Praha 2006, str. 47.

57 P. Urban, Raný Husserl a filosofie jazyka, Praha 2013, str. 157.

58 Tamt., str. 241.

59 E. Husserl, Logická zkoumání, II/1, Zkoumání k fenomenologii a teorii poznání, přel. P. Urban - K. Novotný - H. Janoušek, Praha 2010, str. 394. 
oko vidí“", na téže rovině, a následně to druhé nechá pohltit tím prvním. ${ }^{60}$ Jak způsob vidění, tak to, co vidíme, je podle autora produktem stejných potřeb a stejných předsudků. Z fenomenologické pozice lze pak říci, že „předmět, který jest“", u Goodmana zcela mizí a zůstává jen předmět ,jak jest", což je, přísně vzato, jen předmět, ,jak jej chceme mít“, protože zmizel původní závazek reálného objektu.

\section{Tělo}

S uvedeným problémem souvisí už zmíněný nárok na „nevinné oko“ a jeho rázné odmítání. Rozumím-li totiž dobře, Goodman soudí, že podobnost není privilegovanou formou denotace, jak se obvykle míní, protože by předpokládala existenci tzv. nevinného oka:

„Zdá se tedy, že to, co mám napodobit, je jeden takový aspekt, jeden ze způsobů, jak objekt je nebo jak se jeví. Jistě však ne kterýkoliv z možných - tak např́íklad ne ten, jak se vévoda Wellington jeví opilci přes kapku rosy. Zřejmě půjde spíše o to, jak se objekt jeví normálnímu oku prostému náklonnosti, odporu a osobních zájmů, z vhodné vzdálenosti a příznivého úhlu při dobrém osvětlení, bez pomůcek a nezatížený úvahou ani interpretací. Předmět se zkrátka má napodobit tak, jak ho ve sterilním prostředí vidí nestranné a nevinné oko.“61

Rostislav Niederle pak ve svém komentáři ke Goodmanově koncepci $\mathrm{k}$ řečenému doplňuje:

„Teorie nevinného oka tvrdí, že existuje vnímání světa nedotčené kulturním milieu, vzděláním atd. Takové vnímání se uvažuje jako univerzální antropologická konstanta. Goodman tuto teorii formuluje silně jako reprezentaci věci ,tak, jak je', tedy všech aspektů reprezentovaného - v takovém případě by ovšem věc mohla být reprezentována jen jí samou, a vlastně by to byla spíše prezentace." ${ }^{62}$

Pro diskusi s Goodmanem je zapotřebí poukázat na to, že jeho pojetí vnímání jako záznamu počitkových podnětů na sítnici oka je poněkud zjednodušené a že opomíjí klíčovou roli našeho těla, a to nejen při zpracovávání vjemů, ale i při jejich získávání. Goodman tělo chápe jen jako nulový bod,

60 N. Goodman, Jazyky umění, str. 24.

61 Tamt., str. 23-24.

62 R. Niederle, Reprezentace: podobnost, souvislost, symbol, str. 81. 
z něhož se zraku otevírají různé perspektivy. Takové chápání je však nedostatečné. Tělo nelze při analýze vnímání brát pouze jako orgán vidění, ale také jako orgán pohybu, a je to právě pohyb těla, co doplňuje naše prosté zrakové vjemy o další zkušenosti a o možnost jejich korekcí.

Nevidíme ani jen okem, ale ani ,,jen“ mozkem, jak se často říká, tedy za pomoci určitého intelektuálního výběru, standardu dané kultury nebo jazykové hry a formy života, jak předpokládá Goodman, ale vidíme „tělem“. A to dvojím způsobem.

Za prvé je třeba vzít v potaz fakt, na nějž upozorňuje A. Damasio, totiž že tělo je organický celek, v němž se vnímání „,vnějších“ věcí (a práce oka) vždy váže také na souběžné vnímání vlastních tělesných stavů, poloh jednotlivých orgánů, umístění v prostoru atp.:

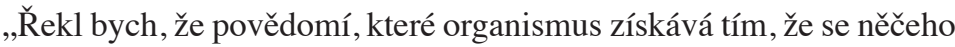
dotýká, že pozoruje okolní krajinu nebo naslouchá nějakému hlasu, případně se pohybuje prostorem $v$ určeném směru, je reprezentováno ve vztahu k tělu, které vyvíjí nějakou činnost. Na počátku (v novorozeneckém období a ještě předtím) vidění, slyšení, samostatné pohyby nebo doteky neexistovaly. Na počátku byl spíše pocit, že je tělo dotýkáno, že tělo něco vidí, slyší nebo se pohybuje.“63

Vytváŕíme si „dynamickou mapu celého organismu“, v níž hrají roli i vjemy kůže a muskuloskeletárního systému. Do nich se tedy „vepisuje“" struktura vnímané reality, ale také struktura zákonitostí zjevování, kloubení jevových konfigurací: „Ve většině procesů vnímání se spolu se senzorickým systémem nebo se systémem odpovídajícím vnímanému objektu současně zapojuje somatosenzorický a motorický systém," upozorňuje Damasio. ${ }^{64}$ „To viděné“ je pak podloženo zkušeností celého těla, což dobře prokazuje naše schopnost vnímat „hloubku“: zrak sám by hloubku neuchopil, ale k jejímu evidování přispívají právě systémy tělesného pohybu. Mysl tedy „nelze pochopit bez určitého druhu zabydlení do těla“ ${ }^{65}$

Tyto úvahy pak dávají jednoznačnou odpověd’ na myšlenkový experiment, známý pod zkratkou „mozek v kádince“. Představme si lidský mozek v určitém roztoku, jenž udržuje život, odkud je připojený umělými čidly na vnější svět. Simulace nervových vzruchů povede k tomu, že

63 A. R. Damasio, Descartesuv omyl. Emoce, rozum a lidský mozek, přel. A. Hesová - L. Motlová, Praha 2000, str. 200.

64 Tamt., str. 201.

65 Tamt. 
v mozku se vytvoří obraz světa podobný tomu, jaký se obvykle vytváří nám všem, když vnímáme, a vznikne tak v posledku myslící entita, která ani nebude vědět, že by mohla mít tělo a vypadat jinak. Tento experiment má prokázat budoucí možnost konstrukce umělé inteligence. Damasio ale doložil, že mozek v kádince by nemohl nikdy dospět ke korektní představě světa, protože nic pro něj nemůže nahradit pobyt v těle, jež se reálně pohybuje, a vytváří tak senzomotorická schémata. ${ }^{66}$

Tělo má však ještě další funkci, která je předpokladem pro naše úvahy o zkreslení a prolínání různých jevových konfigurací (třeba elipsy a kruhu). Má schopnost fakticky se pohybovat, pobývat ve světě a prostřednictvím haptických kontaktů nabízet zraku potřebné varianty toho, co vidí, a tím i základ pro správné uchopení jevící se struktury. Koordináty, jimiž se řídí oko, jsou totiž jiného druhu než koordináty, o něž se opírá tělo, pokud se pohybuje. Vnímání musí tyto parametry sladit.

Uved’me př́íklad, který objasní, co máme na mysli. Jdu-li po rovné cestě, vidím, že se na horizontu sbíhá do jednoho bodu. Oko by mi podalo díky perspektivě informaci pouze o tomto souběhu a rozumný člověk by usoudil, že nemá smysl se po takové cestě vydat vpřed. Kdybych bral v potaz změnu perspektivy jen v tom smyslu, že se na tutéž cestu podívám z jiného bodu, nic by se nemohlo změnit: viděl bych tutéž sbíhavost a můj úsudek by musel být týž. Domnívám se, že právě toto nepřekročitelné zkreslení má Goodman na mysli a že právě tomu odpovídá jeho předpoklad, že potíž by mohlo vyřešit jedině „,nevinné oko“. Abychom se zbavili svého omezení, museli bychom vidět cestu ze všeobjímající pozice, $\mathrm{z}$ ideálního nadhledu: teprve pak bychom mohli evidovat, že se vlastně nesbíhá. Protože to ale není možné, musíme se spolehnout nikoli na to, co vidíme, ale na kulturně nabízenou interpretaci toho, co vidíme, což se zdá potvrzovat tezi, že nikdy nemůžeme vidět svět bez nějaké interpretace. Když si tedy renesanční malî́i mysleli, že použitím geometrické perspektivy dodají zobrazení realistický rys, mýlili se. Vlastně stále interpretovali a chtě nechtě porušovali zákony optiky: cesty kreslili sbíhavě, ale sloupy, které je lemovaly, rovnoběžně, ačkoli i ony by se směrem do „výšky“ měly k sobě sbíhat. Perspektiva je prostě jen „,symbolická forma“, tedy způsob interpretace, verze světa. Goodman z toho pak vyvozuje, že zkreslené možnosti zobrazení (a vyjádření světa) nutně vedou k tomu, že nerealistické jsou nejen „,realistické“ obrazy, ale každý náš popis světa, protože nikdy nemůžeme vidět cestu nesbíhavě, stejně jako nemůžeme vidět sloupy rovnoběžně.

66 Tamt., str. $196 \mathrm{n}$. 
Náš příklad však připouští ještě jedno řešení, které nepředpokládá tuto sugestivní dichotomii - bud’ zkreslení, z něhož se nevymaníme, nebo nesplnitelný předpoklad nevinného oka -, které ovšem zahrnuje roli těla. Když se totiž na cestě pohnu kupředu, mohu nahlédnout, že se úběžník přede mnou posouvá. Posun úběžníku je ale zjevná indikace faktu, že cesta se sbíhá jen domněle, že ve skutečnosti jsou její břehy rovnoběžné. Kdyby tomu tak nebylo a sbíhala se skutečně, úběžník by se $\mathrm{k}$ nám přibližoval. Zde je dobře patrná úloha tělesného pohybu: oko stále vidí totéž, ale tělesný pohyb nám dopřeje zkušenost, která může být účinnou korekcí onoho původního zkresleného vidění. Dủležité je, že se přitom nemusíme posouvat do žádné ideální pozice, dokonce se do jisté míry noříme do perspektivního zkreslení, v němž se nacházíme, mnohem více. Mohu tedy velmi dobře reinterpretovat vizuální parametry původního vjemu, aniž bych $\mathrm{k}$ tomu potřeboval pozici nevinného oka nebo si vypomáhal nějakým kulturně podmíněným výkladem či standardem. Kombinace perspektivní zkratky, nabízející se zraku, s pohybem v reálném světě umožňuje, abych si učinil velmi realistickou a objektivně nosnou představu o tom, jak se to má s parametry cesty navzdory zkreslení, v nichž se mi nabízí. Není zřejmě náhoda, že Goodman si sám zužuje svou pozici tím, že za jediný pohyb, který ve vztahu k perspektivě předpokládá, považuje jen pohyb očí. ${ }^{67}$

Angažmá celého těla je pro roli i povahu našeho vidění světa naprosto klíčové. Jeho anatomie a jeho pohyb, který kopíruje vnější, objektivní strukturu reality, významně přispívají ke kognitivnímu procesu, a to jak před zapracováním informací v mozku (pre-processing), tak v návaznosti na ně (post-processing) ${ }^{68}$ Naši kognitivní zkušenost jednoznačně spoluformují kromě nervového systému také strukturální prvky našeho těla.$^{69}$ Naše motorické reakce nejsou řízeny jen na úrovni mozku, nýbrž jsou zprostředkovány tvarem svalů a úponů, jejich flexibilitou, jejich vztahem k ostatním svalům a kloubům a rovněž jakousi „,historiî" našich pohybů. $^{70}$

Struktura, sestava a schopnost tělesného pohybu neurčují pouze to, jak zakoušíme věci, nýbrž i to, co zakoušíme a jak si činíme svět

67 N. Goodman, Jazyky umění, str. 27.

68 S. Gallagher, Kognitionswissenschaften. Leiblichkeit und Embodiment, in: E. Alloa - T. Bedorf - C. Grüny - T. Klass (vyd.), Leiblichkeit. Begriff, Geschichte und Aktualität eines Konzepts, Tübingen 2012, str. 324.

69 Tamt.

70 Tamt. 
srozumitelným. Experimenty rovněž ukazují, že způsob, jak se pohybujeme nebo situujeme, např́iklad odsunování oproti přisunování, ovlivňuje naše hodnocení věcí, s nimiž máme co do činění. Ustrojení lidského těla určuje jak naše představy prostoru, tak naše pojmové chápání. Jazyk, který toto uchopení ještě dále transformuje, je sám tělesnou praxí. ${ }^{71}$

„Třídit“" svět odpovídajícím způsobem znamená především udělat si jasno o poměru jednotlivých perspektiv, tj. mimo jiné přiřadit správně vizuálním evidencím taktilní zkušenost, a udělat tak „regres“ ke skutečnému tvaru. Nejde tedy jen o prriřazení určitého symbolického řádu nebo pojmového schématu, ale o zjištění základního uspořádání perspektiv, o prolínání jevových forem.

Proto neobstojí Goodmanovo tvrzení, že žádný obraz nemůže být „prvním“, tím, co by snad vytvářelo reálnou, objektivní normu pro výzkum možné podobnosti všech dalších obrazů:

„Bdělý absolutista namítne, že pro náš druhý obraz, na rozdíl od prvního, potřebujeme klíč. Skutečný rozdíl tkví ovšem v tom, že pro ten první máme klíč již v kapse. Pro správné čtení druhého obrazu si musíme interpretační pravidla nejprve najít a pak je použít, zatímco čtení prvního obrazu je v podstatě automatickým návykem. Praxí se symboly staly natolik transparentními, že si vůbec nejsme vědomi žádného úsilí, žádných alternativ, žádné interpretace.“722

Přednost jednoho zobrazení před druhým neurčuje tedy podle Goodmana jeho vztah k realitě, ale pouze snadnost, s jakou ho interpretujeme, a to proto, že je nám tu poskytnut kulturní klíč $\mathrm{k}$ takové interpretaci v podobě sociální sféry, do níž se rodíme. Naše příklady však ukazují, že při vnímání světa a při posuzování, zda naše vjemy uspokojivě reprezentují realitu, nemusíme nutně předpokládat žádný „první obraz“, zakládající jistou interpretační normu. To, čím se fakticky řídíme, není totiž určitý obraz a to, jak se podobá realitě, ale skladba jevících se konfigurací (vazba elipsy na kruh, posun úběžníku sbíhající se cesty). Máme-li předpokládat nějakou „normu“, pak je jí právě toto.

Kdyby si Goodman tento fakt uvědomil, stěží by mohl ve svých úvahách dospět k tvrzení, že pravdivost není žádným kritériem pro hodnocení vědeckých hypotéz:

71 Tamt., str. 326.

72 N. Goodman, Jazyky umění, str. 43. 
„Každý soubor dat bude v souladu s bezpočtem alternativních hypotéz. Nelze mezi nimi zvolit na základě jejich pravdivosti, protože k ní nemáme přímý přístup. Hypotézy posuzujeme spíše podle takových vlastností, jako jsou jednoduchost a přesvědčivost. Tato kritéria nedoplňují pravdivost, užíváme jich s nadějí, že nás dovedou nejblíže k té pravdě, která nejvíce odpovídá našim zájmům. ."73

To, co jsme výše řekli, rovněž rozvolňuje pevnou vazbu, kterou Goodman klade mezi vnímání a jazyk. Podle Goodmana existuje jasná analogie mezi vizuálním zobrazením a slovním popisem:

„Zobrazení i popis se podílí na utváření i charakterizování světa ... užití a klasifikace označení se vždy vztahuje k nějakému systému a alternativních systémů zobrazení i popisů je bezpočet. Na vytváření těchto systémů se různou měrou podílí invence i zvyk. Systém je možno si svobodně zvolit.،"74

Další důsledky, plynoucí z toho, že tímto způsobem do našeho vnímání reality zasahuje jazyk, jsou samožrejmě v Goodmanově pojetí velmi pestré. Nebudu se tu jimi zabývat, pouze upozorním, že sama právě uvedená formulace je nanejvýš problematická. Goodmana přivádí k přesvědčení, že ke světu máme přístup vždy jen skrze nějakou „symbolickou formu“, a následně k tvrzení, že utváření světa můžeme svobodně volit. Ukázalo se ale, že jisté formy jevení a jejich skloubení volit nelze: nemůžeme měnit poměry, za nichž je jedna konfigurace odkazem na povahu konfigurace jiné. Žádný symbolický systém, který bychom chtěli použít, nemůže na této vazbě nic měnit, naopak se jí musí přizpůsobit.

\section{Předmětný smysl}

Je zřejmé, že fenomenologie díky způsobu, jakým analyzuje zkušenost, odhaluje mnohem bohatší strukturu a stratifikaci vnímání a že rozlišuje jiné složky a mechanismy, než na jakých staví Goodmanova teorie. Vnímání není jednoduchý odraz reality ani následná syntéza získaných dat, ale složitý proces, je tím, čemu Husserl říká „,konstituce předmětného smyslu““. ${ }^{75}$ Ten je vždy neurčitý, otevřený, stabilní jen relativně

73 Tamt., str. 200.

74 Tamt., str. 46.

75 Srv. k tomu např. E. Husserl, Analysen zur passiven Synthesis, in: Husserliana, IX, vyd. M. Fleischer, Den Haag 1966, §§ 1-3. 
a fixuje spíše strukturu zjevování, než že by byl kantovskou syntézou našich počitků. Hezky je to vidět na vnímání krychle: z různých rozložení různě natočené krychle dostaneme postupně trojdimenzionální představu (v mentálním prostoru, který ale nemá žádný reálný rozměr), přičemž právě tato představa je, stručně řečeno, oním předmětným smyslem, který pro nás zastupuje reálnou krychli a umožňuje nám, abychom s ní odpovídajícím způsobem nakládali. Tento předmětný smysl jsme ale získali nikoli pouze prostřednictvím paprsků, jež přicházejí od objektu a odrážejí se na sítnici, ani reinterpretací takto získaných obrázků, nýbrž pohybem ve struktuře světa, účastí haptické zkušenosti a hybnou konstitucí, kterou trvale variujeme a korigujeme. Předmětný smysl je proto svou povahou zcela mimo jakékoliv indikátory fyziologických stavů takže jeho ,podobnost“ s originálem je jiného druhu a nelze ji registrovat běžnými postupy. Krychli, pokud ji držíme ve vědomí a pokud jí takto už elementárním způsobem rozumíme, nedržíme v žádných konkrétních liniích, nekroužíme po jejích konturách nějakým vnitřním okem, nenecháváme si jí dráždit žádná nervová zakončení, nemůžeme její působení indikovat žádným měřicím přístrojem.

Kdybychom zkoumali práci sítnice a mozku tak, jak to navrhuje Goodman, možná bychom registrovali reakci očí na mřrižku krychle, na to, jak je umístěna na papîre (na bílém pozadî), okulomotorické pohyby by sledovaly nějakou linii či propojení linií, což by vyvolávalo podráždění nervových zakončení, prričemž díky určité interpretaci bychom si snad sestavili to, čemu bychom později ř́́kali „krychle“. To, co jako krychli vskutku „vidíme“, její předmětný smysl, však držíme ve skutečnosti jinak. Tento předmětný smysl nevznikl mechanickým otiskem okulomotorických pohybů, nebot' jeho „zobrazení“ ve vědomí nemá žádný konkrétní reálný protipól, který by vysílal sledovatelné světelné paprsky, a ani není nesen experimentálně dohledatelnými nervovými vzruchy: vznikal za současného angažmá těla, je zčásti určitým tělesným schématem, nebot' jeho „trojrozměrnost" musela vzejít z haptické zkušenosti s předměty krychlovitého tvaru. Tento předmětný smysl je navíc týž, i když jej vyvolá zrakový vjem zcela jinak strukturovaných linií: „obrázek“ krychle má nekonečné množství variet, čáry na papíre se mohou protínat v mnoha směrech, jejich konfigurace může mít rozličnou orientaci, avšak ,předmětný smysl“ vzejde pokaždé jako více či méně totožný. Jestliže nám ale rozličná konfigurace linií, tvořících geometrický náčrt krychle, umožní držet vposled shodný předmětný smysl, pak nemá význam pátrat po ,podobnosti“ tak, jak po ní pátrá Goodman, a to ani mezi oběma náčrty navzájem, ani mezi nimi a jejich zachycením na naší sítnici. 
Podobnost proto netkví v izomorfii konkrétních čar v realitě a na naší sítnici, nýbrž v tom, že objekt „odpovídá“ skladbě struktury, skrze niž se nám jeví a která řídí konstituci jeho předmětného smyslu. Tady se ztrácejí ty podmínky, za nichž je schopen o podobnosti uvažovat Goodman. Nám to však nebrání říci, že předmětný smysl krychle je podobný krychli v realitě a že krychli zobrazuje správně, nebot' se ve světě nepochybně dobře a správně pohybujeme, držíme-li ho ve svém vědomí. O obrazu, který díky „vtělenému vidění“ o světě získáváme, proto nemá smysl předpokládat, že by měl být jednoduše izomorfní s podobou reálného světa, a následně dokládat, že taková izomorfie není možná. Tělo má „realistické“ informace o světě a drží si jeho obrazy, aniž bychom se mohli dopídit určité „fotografie“ v naší mysli. Jinými slovy, nelze-li takovou fotografii najít, neznamená to, že se musíme zříci realismu a odmítnout „podobnost“ zobrazení a reality. Struktura obrazu, který si o světě spřádáme tělesným pohybem, doprovázeným vizuálními aktivitami, je mnohem složitější než očekávaná fotografie na sítnici oka, není ,primitivně“ podobná realitě, ale přesto jí specificky podobná je, nebot' dešifruje a kóduje klíčové vazby a poměry konfigurací. A naopak, dobrý „realistický“ obraz nemusí být fotografickou kopií nějakého „objektu“, ale výzvou ke konstituci malîrem zamýšleného „předmětného smyslu“ - za pomoci malîřských prostř̌edků, které pak mohou být beze všeho také ,abstraktní“ a ničím nepřipomínat to, co zobrazují. Platí to ve stejném smyslu, v jakém se Cézanne hrdě považoval za „realistu“, a to v mnohem větší míre, než $\mathrm{v}$ jaké byli realisty jeho akademičtí předchůdci. ${ }^{76}$

\section{Závěr}

Nemyslím, že bych svými námitkami podkopal celou stavbu Goodmanovy teorie. To bych byl př́liš troufalý a stěží bych toho byl schopen. ${ }^{77}$ Jsem však přesvědčen, že pokud se zamyslíme detailněji nad východisky, která Goodman přijímá až př́liš samozřejmě, musíme být v některých soudech mnohem opatrnější než Goodman. Především a podstatně

76 Srv. P. Cézanne, Číst přírodu, přel. J. Hamzová, Praha 2001, str. 40.

77 Soustředil jsem se navíc jen na jeden provokativní aspekt Goodmanových úvah. Uznávám také problematické řazení Goodmana mezi „relativisty“. Goodman k němu nicméně zavdává podnět a ti, kteří na něj navazují, k relativismu často dospívají. Odkazuji znovu na knihu T. Marvana Realismus a relativismus. 
platí, že pokud škrtáme jistou formu nápodoby, odvozenou z určité, zúžené analýzy smyslovosti, neškrtáme tím celý realismus.

\section{ZUSAMMENFASSUNG}

Nelson Goodmans Buch Sprachen der Kunst, eine von den meist zitierten und kommentierten Veröffentlichungen zur Theorie der Kunst, behandelt verschiedene Fragen, einschließlich der Frage, ob ein Kunstgegenstand die dargestellte Realität realistisch abzubilden vermag. Goodman behauptet, dass dies nicht möglich ist, weil kein zuverlässiges Kriterium der „Nachahmung“ gefunden werden kann. Diese Position führt zu einer bestimmten Form des Relativismus und des sozialen Konstruktivismus, die dann ihren Ausdruck auch in einer entsprechenden Philosophie der Sprache findet. Mein Beitrag zielt auf die Problematisierung einiger Ausgangsthesen von Goodman und zugleich - vom Standpunkt der Phänomenologie aus - auf die Beurteilung der Problematik, die mit dem sog. ,unschuldigen Auge“ assoziiert wird, weiterhin auf die der Körperlichkeit und der Konstitution des gegenständlichen Sinnes. Es zeigt sich, dass das Problem der Nachahmung sich in unterschiedlicher Art und Weise angehen lässt und dass es dazu nicht nötig ist, die Möglichkeit einer realistischen Abbildung abzulehnen.

\section{SUMMARY}

Nelson Goodman's Languages of Art, one of the most cited and commented publications in theory of art, deals with various questions, including the question whether a piece of art can realistically portray reality. Goodman suggests that it cannot, since a reliable criterion of "imitation" is not to be found. This statement leads to a certain type of relativism and social constructivism, which then find their expression also in philosophy of language. The aim of my paper is to problematize some of Goodman's starting points, and from the view of phenomenology to assess the problems associated with the so-called "innocent eye", corporeality, and the constitution of object sense. It turns out that the problem of imitation can be approached in a different way and that there is no need to reject the possibility of realistic picturing. 